\title{
HUBUNGAN DUKUNGAN KELUARGA DENGAN KECEMASAN IBU HAMIL MENGHADAPI PROSES PERSALINAN DI PUSKESMAS KECAMATAN MAUK KABUPATEN TANGERANG TAHUN 2016
}

\author{
Zuhrotunida, Ahmad Yudiharto \\ Fakultas Ilmu Kesehatan Universitas \\ Muhammadiyah Tangerang
}

\begin{abstract}
ABSTRAK
Kecemasan selama kehamilan dalam proes persalinan yang tidak dapat diatasi ibu dapat menimbulkan ketegangan, menghalangi relaksasi tubuh, menyebabkan keletihan atau bahkan mempengaruhi kondisi janin dalam kandungan, tetapi dengan kehadiran keluarga saat persalinan dapat membuat ibu lebih tenang. Tujuan dari penelitian ini adalah untuk Mengetahui apakah ada hubungan antara karakteristik ibu hamil dan dukungan keluarga dengan kecemasan ibu hamil menghadapi proses persalinan di Puskesmas Mauk. Metode penelitian yang digunakan deskriptif korelasional dengan pendekatan cross sectional. Pengumpulan data menggunakan kuesioner. Pengambilan sampel menggunakan total sampling dengan jumlah 50 sampel. Dan uji analisis data menggunakan uji chi-square. Hasil penelitian menunjukkan tidak ada hubungan antara karakterisitik ibu hamil dengan kecemasan ibu hamil dalam menghadapi proses persalinan dengan $p$-value $>0,05$, tetapi ada hubungan antara dukungan keluarga dengan kecemasan ibu hamil dalam menghadapi proses persalinan di Puskesmas Mauk dengan $p$-value $0,000<0,05$. Diharapkan kepada Puskesmas Mauk untuk Mengadakan kelas Parenting bagi ibu dan keluarga, sehingga dapat meningkatkan pengetahuan dan kesejahteraan ibu serta menciptakan suasana yang nyaman dalam keluarga.
\end{abstract}

\begin{abstract}
Anxiety during pregnancy in facing childbirth Process that cannot be surmounted the mother can cause tension, blocking body relaxation, causing fatigue or even affect the condition of the fetus in the womb, but with the family support at the birth can make mother more relaxed. The purpose of this research is to find out if there is a relationship between the characteristics of pregnant women and family support with maternal anxiety facing childbirth process in the health center Mauk. The research method used descriptive correlation with cross sectional approach. Collecting data using questionnaires.Sampling using total sampling with an amount of 50 samples. And the test data were analyzed using chi-square test. The results showed no relationship between the characteristics of pregnant women with maternal anxiety in facing childbirth process with a $p$-value $>0.05$, but there is a relationship between family support with maternal anxiety in facing childbirth Process in health centers Mauk with a p-value $0.000<$

0.05 . Health center mauk expected to organize Parenting classes for mothers and families, as of to increase the knowledge and well-being of mothers and create a comfortable atmosphere in the family.
\end{abstract}

Keywords: Family Support, Anxiety, Pregnancy. 


\section{PENDAHULUAN}

Kehamilan merupakan proses yang alamiah. Perubahan-perubahan yang terjadi pada wanita selama kehamilan normal adalah bersifat fisiologis, bukan patologis. Oleh karenanya, asuhan yang di berikan pun adalah asuhan yang meminimalkan intervensi. Kehamilan merupakan pengalaman yang sangat bermakna begi perempuan, keluarga dan masyarakat. Perilaku ibu selama masa kehamilannya akan mempengaruhi kehamilannya, perilaku ibu dalam mencari penolong persalinan akan mempengaruhi kesehatan ibu dan janin yang dilahirkan. Tenaga medis harus mempertahankan kesehatan ibu dan janin serta mencegah komplikasi pada saat kehamilan dan persalinan sebagai suatu kesatuan yang utuh (Taufan, 2014).

Salah satu upaya pelayanan kesehatan terpenting adalah meningkatkan kesehatan ibu dan anak (KIA) melalui pelayanan dan pemeliharaan ibu hamil, misalnya dengan program Gerakan Sayang Ibu (GSI). GSI ini bertujuan untuk meningkatkan kualitas hidup perempuan sebagai sumber daya manusia, khususnya pada saat kehamilan dengan merencanakan kehamilan dan persalinan yang sehat (Depkes RI, 2007).

Kehamilan adalah kondisi yang menimbulkan perubahan fisik maupun psikososial seorang wanita karena pertumbuhan dan perkembangan alat reproduksi dan janinnya. Banyak faktor yang mempengaruhi kehamilan, dari dalam maupun dari luar yang dapat menimbulkan masalah, terutama bagi yang pertama kali hamil. Perubahan yang terjadi pada kehamilan akan berdampak pada aspek psikologi kehamilan. Upaya pemeliharaan kesehatan kehamilan tidak semata-mata di tujukan kepada aspek fisik saja, tetapi aspek psikososial juga perlu diperhatikan agar kehamilan dan persalinan berjalan lancar (Susanti, 2008).

Kehamilan merupakan suatu krisis maturitas yang dapat menimbulkan stres, untuk menjadi seorang ibu, seorang remaja harus beradaptasi dari kebiasaan dirawat ibu menjadi seorang ibu yang melakukan perawatan. Seorang dewasa harus mengubah kehidupan rutin menjadi suatu kehidupan yang tidak dapat diprediksi karena merawat bayi (Bobak, 2005).

Menurut Na'im (2010) kehamilan dan persalinan adalah suatu krisis maturitas yang dapat menimbulkan kecemasan atau bahkan stres, tetapi berharga karena wanita tersebut menyiapkan diri untuk memberi perawatan dan mengemban tanggung jawab yang lebih besar. Seiring persiapan menghadapi peran baru, wanita mengubah konsep dirinya agar siap menjadi orang tua. Pertumbuhan ini membutuhkan penguasaan tugas-tugas tertentu, menerima kehamilan, mengidentifikasi peran ibu, mengatur hubungan dengan pasangannya, membangun hubungan dengan anak yang belum lahir, dan mempersiapkan diri menghadapi persalinan.

Salah satu masalah gangguan emosional yang sering ditemui di masyarakat dan menimbulkan dampak psikologis cukup serius adalah ansietas/kecemasan. Menurut Stuart dan Laraia (2005) kecemasan adalah kekhawatiran yang tidak jelas dan menyebar berkaitan dengan perasaan tidak pasti dan tidak berdaya. Keadaan emosi ini tidak memiliki objek yang spesifik, dialami secara subjektif dan dikomunikasikan secara interpersonal.

Kecemasan merupakan suatu respon yang diperlukan untuk hidup, namun bila tingkat cemas ini berat akan mengganggu kehidupan baik secara kualitas maupun kuantitas. Kecemasan dapat disebabkan oleh adanya perasaan takut tidak diterima dalam lingkungan tertentu, pengalaman traumatis akan perpisahan atau 
kehilangan, rasa frustasi akibat kegagalan dalam mencapai tujuan dan ancaman terhadap integritas diri maupun konsep diri (Suliswati, 2005). Salah satu contoh kecemasan yang sering ditemui dalam kehidupan sehari-hari adalah cemas saat menghadapi kejadian traumatik misalkan kecemasan menghadapi persalinan.

Kegelisahan dan kecemasan selama kehamilan merupakan kejadian yang tidak terelakkan, hampir selalu menyertai kehamilan, dan bagian dari suatu proses penyesuaian yang wajar terhadap perubahan fisik dan psikologis yang terjadi selama kehamilan. Perubahan ini terjadi akibat perubahan hormon yang akan mempermudah janin untuk tumbuh dan berkembang sampai saat dilahirkan (Kushartanti, dkk., 2004).

Maramis (2005) juga menyebutkan bahwa sebagian besar calon ibu yang menghadapi kelahiran anaknya dengan perasaan takut dan cemas Semakin tua kehamilan, maka perhatian dan pikiran ibu hamil mulai tertuju pada sesuatu yang dianggap klimaks, sehingga kecemasan dan ketakutan yang dialami ibu hamil akan semakin intensif saat menjelang persalinan (Aprianawati, 2007). Hal senada juga diungkap Hasuki (2007), bahwa pada usia kandungan tujuh bulan ke atas, tingkat kecemasan ibu hamil semakin akut dan intensif seiring dengan mendekatnya kelahiran bayi. Rasa cemas dan takut menjelang persalinan menduduki peringkat teratas yang paling sering dialami ibu selama hamil.

Di Indonesia pada tahun 2008

terdapat

373.000.000 ibu hamil, dan yang mengalami kecemasan dalam mengahadapi proses persalinan ada sebanyak 107.000.000 ibu hamil $(28,7 \%)$ (Pevi Primasnia, 2013). Dari hasil penelitian yang dilakukan oleh Suyuti 2011 (dalam Pevi Primasnia, 2013) di desa Sambirejo Jogoroto mengenai hubungan pengetahuan ibu hamil tentang proses persalinan dengan penurunan tingkat kecemasan menghadapi proses persalinan dengan penurunan tingkat kecemasan menghadapi proses persalinan didapatkan bahwa dari jumlah sampel 48 ibu hamil, sebanyak $29 \mathrm{ibu}$ mengalami kecemasan ringan $(60,4 \%), 6 \mathrm{ibu}$ mengalami kecemasan sedang $(12,5 \%)$, dan $13 \mathrm{ibu}$ mengalami kecemasan berat $(27,1 \%)$.

Kecemasan selama kehamilan dalam proes persalinan yang tidak dapat diatasi ibu menimbulkan ketegangan, menghalangi relaksasi tubuh, menyebabkan keletihan atau bahkan mempengaruhi kondisi janin dalam kandungan. Kondisi tersebut yang mengakibatkan otot tubuh menegang, terutama otot-otot yang berada di jalan rahim ikut menjadi kaku dan keras sehingga sulit mengembang. Tidak hanya itu, emosi yang tidak stabil dapat membuat rasa sakit meningkat. Menjelang persalinan, ibu hamil membutuhkan ketenangan agar proses persalinan menjadi lancar tanpa hambatan. Semakin ibu tenang menghadapi persalinan maka persalinan akan berjalan semakin lancar.

Merujuk pada teori Buffering Hipothesis yang berpandangan bahwa dukungan sosial mempengaruhi kesehatan dengan cara melindungi individu dari efek negatif stress. Perlindungan ini akan efektif hanya ketika individu menghadapi stressor yang berat. Dukungan keluarga terutama dukungan yang didapatkan dari suami akan meimbulkan ketenangan batin dan perasaan senang dalam diri istri.

Bailon dan Maglaya dalam Sudiharto (2007) menyatakan bahwa keluarga adalah dua atau lebih individu yang bergabung karena hubungan darah, perkawinan atau adopsi. Keluarga mempunyai fungsi dasar berupa fungsi afektif, yaitu fungsi internal keluarga untuk pemenuhan kebutuhan psikososial, saling mengasuh dan memberikan cinta kasih, serta saling menerima dan mendukung. (Friedman 
dalam Sudiharto, 2007). Kualitas dan kuantitas dukungan keluarga dinilai dari tiga parameter yaitu, dukungan materi, informasi, dan psikologis. Jadi sangatlah jelas jika dukungan keluarga yang diberikan kepada ibu selama kehamilan hingga menjelang persalinan akan membentuk koping efektif yang dapat mengeliminasi masalah psikologis (kecemasan) ibu.

Dalam studi pendahuluan yang dilakukan peneliti di Puskesmas Kecamatan Mauk tanggal 11 April 2016 pada 10 orang ibu hamil, sebanyak 7 orang ibu hamil mengatakan mengalami kecemasan atau takut menghadapi proses persalinan, sedangkan $3 \mathrm{ibu}$ hamil mengatakan tidak mengalami kecemasan atau tidak takut menghadapi proses persalinan. Alasan mendasar yang membuat ibu hamil cemas menghadapi proses persalinan adalah keadaan yang mungkin terjadi selama persalinan, seperti rasa nyeri pada waktu persalinan, ibu melahirkan normal atau dengan SC, bayi lahir selamat atau tidak, ibu selamat atau tidak, dan pembiayaan setelah persalinan.

Dari latar belakang diatas, maka penulis tertarik melakukan penelitian tentang "Hubungan Dukungan Keluarga Dengan Kecemasan Ibu Hamil Menghadapi Proses Persalinan di Puskesmas Mauk Kabupaten Tangerang".

Tujuan penelitian ini adalah untuk mengetahui apakah ada hubungan antara dukungan keluarga dengan kecemasan ibu hamil menghadapi proses persalinan di Puskesmas Kecamatan Mauk Kabupaten Tangerang.

\section{TINJAUAN TEORITIS}

Kehamilan : Kehamilan adalah dikandungnya janin hasil pembuahan sel telur oleh sel sperma (Kushartanti, 2004). Lamanya kehamilan normal adalah 280 hari (40 minggu), dan tidak lebih dari 300 hari (43 minggu) dihitung dari hari pertama haid terakhir (Winkjosastro,
1992). Istilah medis untuk wanita hamil adalah gravida, sedangkan manusia di dalamnya disebut embrio (mingguminggu awal) dan kemudian janin (sampai kelahiran).

Kehamilan manusia dibagi menjadi tiga periode trimester untuk memudahkan tahap dari perkembangan janin. Trimester I (minggu 1-13) merupakan resiko tinggi terjadi keguguran (kematian alami embrio atau janin), sedangkan pada masa trimester II (minggu 14-26) perkembangan janin dapat dimonitor dan didiagnosa. Trimester III (minggu 27-40) menandakan awal viabilitas, yang berarti janin dapat tetap hidup bila terjadi kelahiran awal alami atau kelahiran dipaksakan.

Menurut Bobak, dkk (2004) persalinan adalah proses pergerakan keluar janin, plasenta, dan membran dari dalam rahim melalui jalan lahir. Persalinan merupakan proses pengeluaran hasil konsepsi (janin atau ari) yang telah cukup bulan atau hidup di luar kandungan melalui jalan lahir atau melalui jalan lain, dengan bantuan atau tanpa bantuan (kekuatan sendiri) (Manuaba,1998). Menurut Federasi Obstetri Ginekologo Internasional, kehamilan di definisikan sebagai fertilasi atau penyatuan dari spermatozoa dan ovum dan dilanjutkan dengan nidasi atau implantasi. Bila dihitung dari saat fertilasi hingga lahirnya bayi, kehamilan normal akan berlangsung dalam waktu 40 minggu atau 10 bulan lunar atau Sembilan bulan menurut kalender internasioanl. Kehamilan terbagi dalam tiga trimester, di mana trimester kesatu berlangsung dalam 12 minggu, trimester kedua 15 minggu (minggu ke-13 hingga ke-27), dan trimester ketiga 13 minggu (minggu ke-28 hingga ke-40).

Persalinan normal menurut World Health Organization (WHO) adalah pada usia kehamilan antara 37-42 minggu, presentasi belakang kepala, persalinan yang dimulai secara spontan (dengan kekuatan ibu sendiri dan melalui jalan lahir), beresiko 
rendah pada awal persalinan, setelah persalinan ibu maupun bayi berada dalam kondisi baik.

Kecemasan : Kecemasan merupakan situasi afektif yang dirasa tidak menyenangkan yang diikuti oleh sensasi fisik yang memperingatkan seseorang akan bahaya yang mengancam. Kecemasan merupakan kondisi mood yang negatif yang ditandai dengan simptom-simptom tubuh, ketegangan fisik dan ketakutan pada hal-hal yang akan terjadi.

Kecemasan yang biasanya bermanfaat untuk bertahan hidup justru menimbulkan hal-hal negatif dalam kehidupan. Hal ini tidak menjadi masalah karena kecemasan hanya terjadi sementara waktu. Apabila kecemasan berlangsung cukup lama, maka individu mulai mencemaskan rasa cemas tersebut. Akibatnya, kecemasan yang terjadi dalam diri individu akan berubah menjadi masalah kecemasan.

Menurut Liftiah (2009) kecemasan yang terjadi pada tingkat sedang dapat berfungsi secara positif. Jika kecemasan sudah intens yang dapat mengacaukan kemampuan seseorang dalam menjalankan kehidupan sehari-hari yang lebih baik, apabila hal tersebut terjadi berarti kecemasan tersebut sudah menjadi gangguan. Gangguan cemas adalah perasaan khawatir yang tidak nyata, tidak masuk akal, tidak sesuai, yang berlangsung terus (intens) atas dasar prinsip yang terjadi (manifes) dan nyata (dirasakan). Perasaan cemas ditandai oleh ketakutan yang difuse, tidak menyenangkan, tidak jelas, seringkali ditandai gejala otonom.

Situasi yang mengancam kesejahteraan individu dapat menimbulkan kecemasan. Ancaman fisik, ancaman terhadap harga diri, dan tekanan untuk melakukan sesuatu di luar kemampuan individu juga dapat menimbulkan kecemasan. Atkinson dkk, (1980) mengatakan bahwa kecemasan adalah emosi yang tidak menyenangkan yang ditandai dengan istilah-istilah seperti kekhawatiran, keprihatinan dan rasa takut yang kadang- kadang kita alami dalam tingkat yang berbeda-beda.

Istilah kecemasan (anxiety) menunjuk kepada keadaan emosi yang menentang atau tidak menyenangkan yang meliputi interpretasi subyektif dan arousal atau rangsangan fisiologis seperti bernafas lebih cepat, menjadi merah, jantung berdebar- debar dan berkeringat. Sedangkan Kartono (2011) menyatakan kecemasan adalah perasaan campuran berisikan ketakutan dan keprihatinan mengenai masa-masa mendatang tanpa sebab khusus untuk ketakutan tersebut.

Karakteristik utama dari gangguan kecemasan umum adalah perasaan cemas dan takut yang berlangsung terusmenerus serta tidak dapat dikendalikan perasaan bahwa sesuatu yang buruk akan terjadi dan rasa ketakutan yang sangat kuat yang muncul pada sebagian besar hari selama periode enam bulan dan tidak disebabkan oleh sesuatu yang berkaitan dengan fisik seperti penyakit, obat-obatan atau karena meminum terlalu banyak kopi. Gejala gangguan tersebut meliputi kesulitan untuk dapat beristirahat atau merasa teragitasi, kesulitan untuk berkonsentrasi, irritability, perasaan tegang yang berlebihan, gangguan tidur dan kecemasan yang tidak diinginkan (Wade dan Tavris 2007).

Dari uraian di atas dapat disimpulkan bahwa kecemasan adalah suatu kondisi psikologis individu yang berupa kekhawatiran dan kegelisahan sebagai bentuk reaksi terhadap adanya kondisi yang menekan serta perasaan cemas dan takut yang berlangsung terus menerus.

Dukungan Keluarga : Keluarga adalah kumpulan dua orang atau lebih yang hidup bersama dengan atau tidak adanya ikatan perkawinan darah atau adopsi dan anggota keluarga saling berinteraksi dan berkomunikasi serta memiliki peran masing- masing dalam keluarga (Friedman, 2010). Keluarga merupakan satuan unit paling kecil dalam masyarakat yang terdiri 
atas kepala keluarga dan individu yang tinggal di bawah satu atap dalam keadaan saling ketergantungan (Departemen Kesehatan RI (1998) dalam Setiadi, 2008). Berdasarkan pada pembahasan di atas, dapat disimpulkan bahwa keluarga adalah bagian terkecil dari masyarakat yang terbentuk atas kumpulan dua orang atau lebih karena ada atau tidaknya ikatan perkawinan darah atau adopsi yang saling berinteraksi menjalankan peran dan tanggung jawab masing-masing. Dukungan keluarga adalah semua bantuan yang diberikan oleh anggota keluarga sehingga akan memberikan rasa nyaman secara fisik dan psikologis pada individu yang sedang merasa tertekan atau stress.

Dukungan keluarga adalah suatu proses hubungan antara keluarga dengan lingkungan sosialnya yang dapat diakses oleh keluarga yang dapat bersifat mendukung dan memberikan pertolongan kepada anggota keluarga (Friedman, 2010). Widyastuti (2009) menyatakan bahwa dukungan keluarga dapat berasal dari sumber internal yang meliputi dukungan dari suami, istri, atau dukungan dari saudara kandung dan keluarga besar.

Ayah-ibu kandung maupun mertua sangat mendukung kehamilan ini, ayah ibu kandung maupun mertua sering berkunjung pada saat kehamilan, seluruh keluarga berdoa untuk keselamatan ibu dan bayi, walaupun ayah ibu kandung maupun mertua ada di daerah lain, sangat di dambakan dukungan dari telephone, surat ataupun doa dari jauh, (Yeyeh Rukiyah, 2013).

\section{Dukungan Emosional}

Dukungan yang diberikan berupa rasa empati dan perhatian kepada individu, sehingga membuatnya merasa lebih baik, mendapatkan kembali keyakinannya, merasa dimiliki dan dicintai oleh orang lain (Sarafino, 2004). Menurut Nugroho (2000), dukungan emosional merupakan suatu bentuk dukungan berupa rasa aman, cinta kasih, memberi semangat, mengurangi putus asa dan rendah diri sebagai akibat dari ketidakmampuan fisik. Dukungan emosional dalam keluarga akan mempengaruhi pertumbuhan dan perkembangan anggota keluarga (Friedman, 2010).

\section{Dukungan Penilaian}

Penilaian mengacu pada kemampuan untuk menafsirkan lingkungan dan situasi diri dengan benar dan mengadaptasi suatu perilaku dan keputusan diri secara tepat (Karyuni, 2008). Keluarga sebagai pemberi bimbingan dan umpan balik atas pencapaian anggota keluarga dengan cara memberikan support, pengakuan, penghargaan, dan perhatian sehingga dapat menimbulkan kepercayaan diri pada individu.

\section{Dukungan Instrumental}

Keluarga menjadi sumber pemberi pertolongan secara nyata. Misalnya bantuan langsung dari orang yang diandalkan seperti memberikan materi, tenaga, dan sarana. Manfaat dari diberikannya dukungan ini yaitu individu merasa mendapat perhatian atau kepedulian dari lingkungan keluarga.

\section{Dukungan Informasi}

Keluarga berfungsi sebagai pemberi informasi, nasihat, dan bimbingan kepada anggota keluarga untuk menyelesaikan permasalahan yang dihadapi. Manfaat dari dukungan ini dapat menekan munculnya stressor karena informasi tertentu dapat memberikan pengaruh sugesti pada individu.

\section{METODE PENELITIAN}

Penelitian ini merupakan penelitian deskriptif korelasional dengan rancangan penelitian menggunakan desain cross sectional (potong lintang). Desain penelitian cross sectional yaitu desain penelitian untuk mempelajari dinamika korelasi antar faktor- faktor resiko dengan efek, dengan cara pendekatan, observasi atau pengumpulan data sekaligus pada suatu saat. Artinya tiap subjek penelitian 
hanya di observasi sekali saja dan pengukuran dilakukan terhadap status karakter atau variabel subjek pada saat pemeriksaan, hal ini tidak berarti bahwa semua subjek penelitian di amati pada waktu yang sama. Desain ini dapat mengetahui dengan jelas mana yang jadi pemajan dan outcome, serta jelas kaitannya hubungan sebab akibatnya (Notoatmodjo, 2012).

Desain penelitian cross sectional juga bisa di katakan adalah desain penelitian deskriptif korelasi yang bertujuan untuk mengetahui hubungan antar variable dimana variable independen dan variable dependen diidentifikasi pada satu satuan waktu. (Dharma. 2011). Variabel independen dalam penelitian ini adalah dukungan keluarga, dan variabel dependen dalam penelitian ini adalah kecemasan ibu hamil menghadapi proses persalinan. Tujuannya untuk mengetahui hubungan dukungan keluarga dengan kecemasan ibu hamil menghadapi proses persalinan . Variabel penelitian ini adalah univariat dan bivariat yaitu dukungan keluarga dengan kecemasan ibu hamil menghadapi proses persalinan.

\section{Teknik Pengambilan Sampel :} Teknik pengambilan sampel yang digunakan dalam penelitian ini adalah menggunakan teknik total sampling yaitu teknik penentuan sampel dengan mengambil seluruh anggota populasi sebagai responden atau sampel. Peneliti mengambil sampel dari seluruh ibu hamil trimester III yang melakukan pemeriksaan kehamilan di Puskesmas Kecamatan Mauk Kabupaten Tangerang yang berjumlah 50 orang.

Instrument penelitian : Dalam kuesiner kecemasan, peneliti mengadopsi kuesioner baku dari Zung, WW, 1965. Sedangkan dalam kuesioner dukungan keluarga peneliti mengadopsi kuesioner dari Na'im tahun 2010.

\section{ANALISA DATA}

Analisa Univariat : Analisa ini digunakan untuk mengetahui distribusi frekuensi dengan menggunakan program computer SPSS for Windows 16.0 dari variabel yang diteliti baik variabel independen (dukungan keluarga) dan variabel dependen (kecemasan ibu hamil), setiap variabel yang ada selanjutnya dilakukan analisa terhadap tampilan data.

Analisa Bivariat : Analisa ini dilakukan untuk mengetahui adanya hubungan antara independen (dukungan keluarga) dengan variabel dependen (kecemasan ibu hamil) atau mengetahui adanya hubungan dukungan keluarga dengan kecemasan ibu hamil menghadapi proses persalinan di Puskesmas Mauk yaitu dengan analisa menggunakan program computer SPSS for windows 16.0. Adapaun rumus uji statisik tersebut dengan rumus chi square Test (Dalam Wijayanto. 2010).

\section{HASIL PENELITIAN}

Penelitian ini dilakukan di Puskesmas Kecamatan Mauk Kabupaten Tangerang pada pertengahan bulan juni sampai juli dengan jumlah responden sebanyak 50 responden.

Analisa Univariat : Analisis univariat untuk mengetahui distribusi frekuensi dari variabel independen dan dependen terhadap hubungan dukungan keluarga dengan kecemasan ibu hamil dalam menghadapi proses persalinan.

\section{Distribusi frekuensi kecemasan responden di Puskesmas Kecamatan Mauk Tangerang 2016}

\begin{tabular}{|l|c|c|}
\hline \multicolumn{1}{|c|}{ Kategori } & Jumlah & Presentase \\
\hline Tidak cemas & 29 & $58 \%$ \\
\hline Cemas & 21 & $42 \%$ \\
\hline Total & 50 & $100 \%$ \\
\hline
\end{tabular}


Pada tabel diatas memperlihatkan bahwa dari 50 responden, ibu hamil yang mengalami kecemasan terdapat sebanyak $21(42 \%)$ responden, dan responden ibu hamil yang tidak mengalami kecemasan terdapat sebanyak 29(58\%) responden.

\section{Distribusi frekuensi dukungan keluarga responden di Puskesmas Kecamatan Mauk Tangerang 2016}

\begin{tabular}{|l|l|l|}
\hline \multicolumn{1}{|c|}{ Kategori } & Jumlah & Presentase \\
\hline $\begin{array}{l}\text { Dukungan } \\
\text { kurang }\end{array}$ & 15 & $30 \%$ \\
\hline $\begin{array}{l}\text { Dukungan } \\
\text { baik }\end{array}$ & 35 & $70 \%$ \\
\hline Total & 50 & $100 \%$ \\
\hline
\end{tabular}

Pada tabel diatas memperlihatkan bahwa dari 50 responden, ibu hamil yang mendapat dukungan keluarga baik terdapat sebanyak $30(70 \%)$ responden, dan responden ibu hamil yang mendapat dukungan keluarga buruk/kurang terdapat sebanyak $15(30 \%)$ responden.

Analisis Bivariat : Analisis bivariat dilakukan untuk mencari hubungan antara variabel dependen dengan variabel independen. Pengujian ini menggunakan uji chi-square. Dikatakan ada hubungan yang bermakna secara statistik jika diperoleh nilai $\mathrm{p}<0,05$.

Hubungan antara dukungan keluarga dengan kecemasan ibu hamil menghadapi proses persalinan di Puskesmas Kecamatan Mauk Kabupaten Tangerang 2016

\begin{tabular}{|c|c|c|c|c|c|}
\hline \multirow{2}{*}{$\begin{array}{c}\text { Dukungan } \\
\text { Keluarga }\end{array}$} & \multicolumn{2}{|c|}{ Kecemasan } & \multirow{2}{*}{ Total } & \multirow{2}{*}{$\begin{array}{c}\text { OR } \\
(95 \% \\
\text { CI })\end{array}$} & \multirow{2}{*}{$\begin{array}{c}P \text { - } \\
\text { value }\end{array}$} \\
\hline & $\begin{array}{l}\text { Tidak } \\
\text { cemas }\end{array}$ & Cemas & & & \\
\hline $\begin{array}{c}\text { Dukungan } \\
\text { kurang }\end{array}$ & $\begin{array}{c}5 \\
10 \%\end{array}$ & $\begin{array}{c}19 \\
38 \%\end{array}$ & $\begin{array}{r}24 \\
48 \%\end{array}$ & \multirow{3}{*}{$\begin{array}{c}0,097 \\
0,026 \\
- \\
0,360\end{array}$} & \multirow{3}{*}{0,000} \\
\hline $\begin{array}{l}\text { Dukungan } \\
\text { baik }\end{array}$ & $\begin{array}{c}19 \\
38 \%\end{array}$ & $\begin{array}{c}7 \\
14 \%\end{array}$ & $\begin{array}{c}26 \\
52 \%\end{array}$ & & \\
\hline Total & $\begin{array}{c}24 \\
48 \%\end{array}$ & $\begin{array}{c}26 \\
52 \%\end{array}$ & $\begin{array}{c}50 \\
100 \%\end{array}$ & & \\
\hline
\end{tabular}

Pada tabel diatas memperlihatkan bahwa dari 50 responden, ibu hamil yang mengalami kecemasan terdapat sebanyak 21(42\%) responden, dan responden ibu hamil yang tidak mengalami kecemasan terdapat sebanyak $29(58 \%)$ responden.

Pada tabel diatas terlihat hasil uji chi-square sebanyak 24(48\%) dengan dukungan keluarga kurang dan terdapat $5(10 \%)$ responden tidak mengalami kecemasan, dan terdapat sebanyak $26(52 \%)$ respoden dengan dukungan keluarga baik dan terdapat $19(38 \%)$ responden tidak mengalami kecemasan. Hasil uji statistic nilai $\mathrm{p}=$ $0,000<0,05$ berarti ada hubungan antara dukungan keluarga dengan kecemasan ibu hamil dalam menghadapi proses persalinan. Dan dari hasil analisis di peroleh juga nilai $\mathrm{OR}=0,097$ artinya ibu hamil yang mendapatkan dukungan keluarga baik mempunyai peluang 0,097 kali untuk mengalami kecemasan di banding ibu hamil yang mendapat dukungan keluarga kurang.

\section{PEMBAHASAN}

Hasil uji chi-square sebanyak 24(48\%) dengan dukungan keluarga kurang dan terdapat $5(10 \%)$ responden tidak mengalami kecemasan, dan terdapat sebanyak 26(52\%) respoden dengan dukungan keluarga baik dan terdapat $19(38 \%)$ responden tidak mengalami kecemasan. Hasil uji statistic nilai $\mathrm{p}=$ $0,000<0,05$ berarti ada hubungan antara dukungan keluarga dengan kecemasan ibu hamil dalam menghadapi proses persalinan. Dan dari hasil analisis di peroleh juga nilai $\mathrm{OR}=0,097$ artinya ibu hamil yang mendapatkan dukungan keluarga baik mempunyai peluang 0,097 kali untuk mengalami kecemasan di banding ibu hamil yang mendapat dukungan keluarga kurang.

Dalam hal ini peneliti berpendapat bahwa dukungan keluarga yang di berikan kepada ibu hamil dalam menghadapi 
proses persalinan sangatlah di perlukan untuk menurunkan tingkat kecemasan ibu hamil tersebut, dukunga dari keluarga sangat di perlukan olehn ibu hamil yang akan menghadapi proses persalinan, hal ini di karenakan ibu hamil tersebut merasa tidak sendiri dalam menghadapi proses persalinan nanti, melainkan ada keluarga yang selalu memberikan dukungan kepada ibu hamil tersebut sehingga ibu hamil tersebut bisa merasa lebih tenang dalam menghadapi proses persalinan nanti.

Hasil penelitian di atas sama dengan hasil penelitian Asnawir Arifin tahun 2015 dengan judul hubungan dukungan keluarga dengan kecemasan ibu hamil menghadapi proses persalinan di puskesmas budilatama kecamatan gadung kabupaten buol propinsi sulawesi tengah, dengan hasil bahwa ada hubungan yang signifikan antara dukungan keluarga dan kecemasan ibu hamil, dan juga sesuai dengan hasil penelitian Pevi Primasnia tahun 2013 dengan judul hubungan pendampingan suami dengan tingkat kecemasan ibu primigravida dalam menghadapi proses persalinan kala 1 di rumah bersalin kota ungaran dengan hasil adanhya hubungan yang signifikan antara pendampingan suami dengan tingkat kecemasan ibu primigravida dalam menghadapi proses persalinan.

Hal ini juga sejalan dengan teori yang menjelaskan keluarga sebagai fungsi afektif, yaitu fungsi keluarga yang berhubungan dengan fungsi internal keluarga dalam memberikan perlindungan psikososial dan dukungan terhadap anggota keluarga. Keluarga sebagai sumber cinta, pengakuan, penghargaan, dan sumber dukungan primer. (Satir, 1972, dalam Friedman, 2010)

\section{KESIMPULAN}

Berdasarkan hasil penelitian dan pembahasan yang dilakukan mengenai hubungan dukungan keluarga dengan kecemasan ibu hamil menghadapi proses persalinan di Puskesmas Mauk Kabupaten
Tangerang tahun 2016, dapat disimpulkan bahwa ada hubungan antara dukungan keluarga dengan kecemasan ibu hamil menghadapi proses persalinan di Puskesmas Mauk, hal ini terlihat dari nilai $\mathrm{P}$ value yaitu $0,000<0,05$.

\section{SARAN}

\section{Untuk Puskesmas Mauk}

Memperhatikan kondisi psikologi ibu saat melakukan ANC, yaitu mengidentifikasi kecemasan dan ketakutan yang dialami oleh ibu yang akan mempersiapkan persalinan sehingga kekhawatiran dan kecemasan yang terjadi pada ibu dapat teridentikasi. Mengadakan kelas Parenting bagi ibu dan keluarga, sehingga dapat meningkatkan pengetahuan dan kesejahteraan ibu serta menciptakan suasana yang nyaman dalam keluarga.

\section{Untuk Tenaga Kesehatan}

Meningkatkan peran serta tenaga kesehatan dalam memberikan promosi kesehatan kepada ibu hamil pada saat antenatal care tentang keadaan fisik dan psikis, perawat maupun tenaga kesehatan lainnya disarankan untuk meningkatkan caring dan empati pada ibu hamil, misalkan memberikan penjelasan dan informasi lebih mengenai kehamilan dan persalinan untuk mengurangi kecemasan.

\section{Untuk Pendidikan Kesehatan}

Meningkatkan dan mengembangkan ilmu keperawatan jiwa tentang kecemasan, terutama Teori yang dikemukakan oleh Stuart dan Laraia, untuk kesehatan ibu dan anak tidak hanya memberikan asuhan pada ibu hamil mengenai kondisi fisik tetapi juga mengenai psikologi agar dapat memberikan asuhan secara optimal.

\section{Untuk Peneliti Selanjutnya}

Disarankan perlu adanya penelitian lebih lanjut tentang kecemasan dengan pendekatan yang berbeda (kualitatif) dan sampel yang diteliti lebih spesifik 
(pasien yang mengalami kecemasan berat atau panic, atau pada pasien yang

\section{DAFTAR PUSTAKA}

American Psychiatric Association. 2005. Diagnostic and Statistical Manual of Mental Disorders. Washington DC : American Psychiatric Press, Inc.

Aprianawati, R.B., (2007) Hubungan antara Dukungan Keluarga dengan Kecemasan Ibu Hamil Menghadapi Kelahiran Anak Pertama pada Masa Triwulan Ketiga. Yogyakarta : Universitas Gajah Mada.

Arikunto, S. 2006. Prosedur Penelitian Suatu Pendekatan Praktek. Edisi Revisi V. Jakarta : Rineka Cipta.

Atkinson, Rita L. 1980. Pengantar Psikologi Jilid 2. Jakarta: Erlangga.

Azwar, Saifudin. 2007. Metode Penelitian. Yogyakarta : Pustaka Pelajar Offset. Hal 57, 94.

Bailon. Maglaya., 2007. Family health nursing the process. Filipines. UP College on Nursing Diliman.

Bobak, L.M; D.L Lowdermilk; and M.D Jensen. Keperawatan maternitas Edisi 4. Alih bahasa Wijayarini, M.A \& Anugerah, P. I. Jakarta: EGC, 2004.

Bobak. 2005. Buku Aja Keperawatan Maternitas. Jakarta: EGC.

Budiman, A.R. 2013. Pengetahuan dan Sikap dalam Penelitian Kesehatan. Jakarta:Salemba Medika.

Carole Wade dan Carole Tavris. 2007. Psikologi Edisi Kesembilan Jilid 1. Jakarta: Erlangga.

David Barlow. 2006. Essential Abnormal Psychology. Yogyakarta : Pustaka Belajar.

Depdiknas. 2003. Artikel Pendidikan di Indonesia

Http://id.m.wikipedia.org/wiki/pendi dikan di indonesia: diakses tanggal 20 April 2016.

Depkes RI, United Nations Population Found, (2007). Yang Perlu Diketahui Petugas Kesehatan tentang: Kesehatan menggunakan terapi obat antiansietas) sehingga kecemasan lebih terlihat lagi.

Reproduksi. Jakarta : Departemen Kesehatan Republik Indonesia.

Dharma, K.K. 2011. Metodologi Penelitian Keperawatan. Jakarta: CV. Trans Info Media.

Fausiah, F dan Widuri, J. 2005. Psikologi Abnormal Klinis Dewasa. Jakarta: UIPress.

Fitriani, S. 2011. Promosi kesehatan, Cetakan 1. Yogyakarta:Graha Ilmu.

Friedman, Marilyn, (2003).

Keperawatan Keluarga, Teori dan Praktek, Jakarta : EGC.

..... 2010. Buku Ajar Keperawatan Keluarga: Riset, teori, dan praktik Ed 5. Jakarta: EGC.

Halgin, Richard P. 2010. Psikologi Abnormal Perspektif Klinis pada Gangguan Psikologis. Jakarta: Salemba Humanika.

Hasuki, I., 2007. Buku Saku Perawatan Kesehatan Ibu dan Anak. EGC: Jakarta.

Hawari. 2001. Keperawatan Kesehatan Holistik Pada Gangguan Jiwa. Jakarta:Gaya Baru.

Jiwo, T. 2012. Materi bahan kuliah Anxiety (kecemasan).

Kartono, K. 1992. Psikologi Wanita Jilid 2: Mengenal Wanita Sebagai Ibu Dan Nenek. Bandung:Mandar Maju.

Karyuni, Pamilah Eko, dkk. 2008. Buku Ajar Keperawatan Jiwa. Jakarta: EGC.

Kumala P. 2007. Kamus Saku Kedokteran. Jakarta:Penerbit Buku kedokteran.

Kushartanti, Hanim, L., Nuhriawangsa, L., Sumarni, (2004). Keadaan Kecemasan dan Depresi pada Emesis Gravidarum di RSUP. Dr. Sardjito dan Klinik Trisnowati Yogyakarta. Yogyakarta : Universitas Sebelas Maret.

Liftiah. 2009. Psikologi Abnormal. Semarang: Widya karya. 
Manuaba Ida Bagus Gde, 1998, Ilmu kebidanan Penyakit Kandungan dan Keluarga Berencana untuk Pendidikan, EGC : Jakarta.

Maramis, W.F., $2005 . \quad$ Catatn Ilmu kedokteran Jiwa, Cetakan Kesembilan. Surabaya : Airlangga University Press.

Na'im, Nur, Jannatun, (2010). Hubungan Dukungan Keluarga dengan Tingkat Kecemasan Ibu Primipara Menghadapi Persalinan di Puskesmas Pamulang Kota Tangerang Selatan. Jakarta : Universitas Islam Negeri Syarif Hidayatullah.

Narbuko. 2004. Metode Penelitian. Jakarta: Bumi Aksara.

Notoatmodjo. 2003. Pendidikan dan Perilaku Kesehatan. Jakarta: Rineka Cipta.

..... 2012. Metodologi penelitian kesehatan. PT Rineka Citra : Jakarta. Nugroho, W. 2000. Keperawatan Gerontik. Jakarta: EGC.

Nursalam. 2003. Konsep dan Penerapan Metodologi Penelitian Ilmu Keperawatan. Jakarta: Penerbit Salemba Medika.

Pevi. P, (2013) hubungan pendampingan suami dengan tingkat Kecemasan ibu primigravida dalam menghadapi proses Persalinan kala $i$ di rumah bersalin kota ungaran. Semarang: Poltekes Kemenkes semarang.

Sabri Luknis, S.P. (2008). Statistik Kesehatan. Jakarta: Rajawali Pers.

Sarafino. 2004. Health Psychology: Biopsychososial interaction. New York: John Wilky and Sons In.

Sarwono Prawirohardjo. 2014. Ilmu Kebidanan.Jakarta : PT Bina Pustaka.

Sudiharto, (2007). Asuhan Keperawatan Keluarga dengan Pendekatan Keperawatan Transkultural. Jakarta : EGC.

Sugiyono. 2011. Metode Penelitian Kuantitatif, Kualitatif, dan $R \& D$. Bandung:AFABETA, $c v$.
Susanti. 2008.psikologi kehamilan. Penerbit buku kedokteran. EGC; Jakarta.

Suwadirman. (2004). Hubungan antara dukungan keluarga dengan beban keluarga untuk mengikuti regimen terapeutik pada keluarga klien halusinasi RSUD serang. Tesis. Jakarta. FIK.

Stuart, G.W and Sundeen, S.J; alih bahasa Ramona,dkk. Buku saku keperawatan Jiwa Edisi 3.Jakarta: EGC, 1998.

..... G. W., \& Laria, 2005. M.T. Principles and practice of psychiatric nursing. (8th ed.). St.Louis: Mosby.

Subana, M dan Sudrajat. 2005. DasarDasar Penelitian Ilmiah. Bandung: Pustaka Ilmiah.

Sudaharto, S.Kp, M.Kes. 2007. Asuhan Keperawatan Keluarga dengan Pendekatan Transkultural. Penerbit Buku Kedokteran:EGC.

Suliswati, dkk., 2005 konsep Dasar Keperawatan KesehatanJjiwa, Jakarta : EGC.

Taufan, 2014. Askep kehamilan (cetakan pertama). Yogyakarta. Nuhu Medika.

Tobing. 2009. Hamil di Usia 20,30, 40 tahun. Diambil tanggal 13 april 2006.

Widyastuti. 2009. Kesehatan Reproduksi. Jakarta:Fitra Maya.

Wijayanto. 2010. Uji Chi- Square. http://eprints.undip.ac.id/6796/1/CHI -KUADRAT.pdf diakses pada tanggal 13 April 2016.

Wiknjosastro, 2006. Ilmu Kebidanan. Jakarta. Yayasan Bina Pustaka Prawirohardjo.

Wiramihardja, Sutardjo A. 2005. Pengantar Psikologi Abnormal. Bandung: Refika Aditama.

Yeyeh Rukiyah. 2013. Asuhan Kebidanan 1 (Kehamilan). CV. Trans Info Media.

Zung, W.W.K. 1997. Rating Anxiety for anxiety disorder physychosomatic. USA: Mosby Company. 